(2) Open Access Full Text Article

\title{
Sex ratio of infants born to women with severe chronic constipation
}

This article was published in the following Dove Press journal:

Clinical Epidemiology

4 March 2011

Number of times this article has been viewed

\section{$\mathrm{WH}$ James}

Department of Genetics, Evolution and Environment, University College London, London, UK
Correspondence: $\mathrm{WH}$ James Department of Genetics, Evolution and Environment, University College London, 4 Stephenson Way, London NWI 2HE, UK

Emailwhjames@waitrose.com
Czeizel et al ${ }^{1}$ reported a significant male excess among infants born to women with severe chronic constipation as contrasted with controls. Czeizel and colleagues were unable to account for this phenomenon, so I wish to suggest an explanation. Women (as contrasted with men) are disproportionately often affected by constipation, which is frequently aggravated by pregnancy and ameliorated after delivery, ${ }^{2}$ so it is reasonable to wonder whether constipation has hormonal causes. Large quantities of data have been adduced to support the hypothesis that the sex ratios (proportions male) of mammalian (including human) offspring are partially controlled by the hormone levels of both parents around the time of conception. ${ }^{3-5}$ The probability of a male birth varies positively with some function of the form:

$$
(\mathrm{E}+\mathrm{T}) /(\mathrm{G}+\mathrm{P})
$$

where $\mathrm{E}, \mathrm{T}, \mathrm{G}$, and $\mathrm{P}$ are sex-standardized concentrations of parental estrogen, testosterone, gonadotrophins, and progesterone around the time of conception.

$\mathrm{Kamm}$ et $\mathrm{al}^{6}$ reported that women with severe constipation have a 'consistent reduction of steroid hormones'. However, Maruti et $\mathrm{al}^{7}$ suggested that women with low bowel motility (as contrasted with those with high bowel motility) had high serum estrogen levels, and a higher risk for breast cancer. And Vesna and Neli ${ }^{8}$ reported that vaginal estrogen replacement therapy was associated with constipation. Accordingly I suggest that women with severe constipation may have high estrogen concentrations and, for this reason, have a statistical excess of sons.

\section{Disclosure}

The author reports no conflicts of interest in this work.

\section{References}

1. Czeizel AE, Puha EH, Banhidy F. Sex ratio of newborn infants born to pregnant women with severe chronic constipation. Clin Epidemiol. 2010;2:217-219.

2. Gonenne J, Esfandyan T, Camilleri M, et al. Effect of female sex hormone supplementation and withdrawal on gastrointestinal and colonic transit in postmenopausal women. Neurogastroenterol Motil. 2006;18:911-918

3. James WH. Evidence that mammalian sex ratios at birth are partially controlled by parental hormone levels at the time of conception. J Theor Biol. 1996;180:271-286.

4. James WH. Further evidence that mammalian sex ratios at birth are partially controlled by parental hormone levels around the time of conception. Hum Reprod. 2004;19:1250-1256. 
5. James WH. Evidence that mammalian sex ratios at birth are partially controlled by parental hormone levels around the time of conception. J Endocrinol. 2008;198:3-15.

6. Kamm MA, Farthing MJ, Lennard-Jones JE, Perry LA, Chard T. Steroid hormone abnormalities in women with severe idiopathic constipation. Gut. 1991;32:80-84.

7. Maruti SS, Lampe JW, Potter JD, Ready A, White E. A prospective study of bowel motility and related factors on breast cancer risk. Cancer Epidemiol Biomarkers Prev. 2008;17:1746-1750.

8. Vesna A, Neli B. Benefit and safety of transdermal estrogen regimen during vaginal hysterectomy (a controlled trial). Maturitas. 53: 282-298.

\section{Sex ratio of infants born to women with severe chronic constipation: authors' response}

\section{Andrew E Czeizel'; Erzsébet H Puhó'; Ferenc Bánhidy²}

'Foundation for the Community Control of Hereditary Diseases, ${ }^{2}$ Second Department of Obstetrics and Gynecology, Semmelweis University, School of Medicine, Budapest, Hungary

\section{Correspondence: Andrew E Czeizel}

Foundation for the Community Control of Hereditary Diseases, 1026

Budapest, Törökvész lejtõ 32. Hungary

Email czeizel@interware.hu

We thank Dr James for his comments to help us better understand an unexpected finding of our previous study. The objective of our 10-year project was a systematic analysis of all maternal diseases during the study pregnancy that may effect the fetal development, particularly for the risk of congenital abnormalities and preterm birth, the two most important components of infant mortality and handicaps in the large population-based Hungarian Case-Control Surveillance of Congenital Abnormlities. ${ }^{1}$ This research series resulted in some unexpected findings, one of which was the excess of male infants born to pregnant women with severe chronic constipation. In fact, we - medical geneticist (AEC), mathematician (HEP), and obstetrician (FB) - were not able to find an appropriate explanation for this unexpected new finding. Our hope was that after the publication of the short report of these data, experts in this field would provide a more reasonable hypothesis for this phenomenon. We are happy that our hopes were realized with Dr James' letter.

\section{Disclosure}

The authors report no conflicts of interest in this work.

\section{Reference}

1. Ács N, Bánhidy F, Czeizel AE. Congenital Abnormalities and Preterm Birth Related to Maternal Illnesses During Pregnancy. Dordrecht, Germany: Springer; 2010.
Clinical Epidemiology

\section{Publish your work in this journal}

Clinical Epidemiology is an international, peer-reviewed, open access journal focusing on disease and drug epidemiology, identification of risk factors and screening procedures to develop optimal preventative initiatives and programs. Specific topics include: diagnosis, prognosis, treatment, screening, prevention, risk factor modification, systematic

\section{Dovepress}

reviews, risk \& safety of medical interventions, epidemiology \& biostatical methods, evaluation of guidelines, translational medicine, health policies \& economic evaluations. The manuscript management system is completely online and includes a very quick and fair peer-review system, which is all easy to use. 